\title{
KONFUSIANISME DALAM KEBUDAYAAN CINA MODERN
}

\author{
Dewi Hartati
}

\begin{abstract}
Abstrak
Konfusianisme bertujuan untuk mendidik dan menekankan agar manusia dapat melayani negara dan masyarakat. Untuk menahami ajaran Konfusius tersebut perlu dipahami kitab Daxue 大学 (Ajaran Agung) yang berisi ajaran mengenai etika, yaitu etika dalam keluarga, masyarakat dan bernegara. Konfusianisme bukanlah suatu ideologi pada tingkat negara atau tingkat nasional tetapi lebih ke tingkat personal.Konfusianisme yang menekankan pengolahan diri dalam tingkat personal inilah yang dapat bertahan sekian lama dan dihormati serta menyebar ke seluruh tingkatan dan tetap ada dalam dunia modern.
\end{abstract}

\section{Kata kunci}

Konfusius, Ajaran Agung, Konfusianis Personal, Konfusianis Patriarkat, Konfusianis Birokrat, Konfusianis Kerajaan.

\begin{abstract}
Confucianism aims to educate and emphasize for people to serve the state and society. To understand Confucianism is necessary to understand the book of Daxue 大学 (Great Teaching), which contains teachings on ethics, the ethics of family, society and state. Confucianism is not an ideology at the state level or national level but rather to a personal level. Confucianism, which emphasizes self-processing in a personal level is what can survive for so long and respected, and spread to all levels and persists in the modern world.
\end{abstract}

\section{Keywords}

Confucius, the Great Teachings, Personal Confucianism, Confucian Patriarchate, Confucian bureaucrats, Confucian kingdom.

\section{PENDAHULUAN}

Konfusianisme bertujuan untuk mendidik dan menekankan agar manusia dapat melayani Negara dan masyarakat. Untuk memahami ajaran Konfusius tersebut perlu dipahami Kitab Daxue (Ajaran Agung) yang berisi ajaran mengenai etika, yaitu etika dalam keluarga, masyarakat, dan bernegara. Ajaran Agung merupakan inti dari dari Ajaran Konfusius untuk mendidik dan membangun manusia mencapai prestasi. Untuk mencapai pengetahuan tertinggi penguasa, pemimpin, dan orang terpelajar harus menciptakan keteraturan dalam wilayah masing-masing. Untuk dapat menciptakan keteraturan dalam 
masyarakat, mereka harus dapat mengatur keluarganya sendiri.Untuk mengerjakan semua hal tersebut pertama-tama manusia harus dapat mengolah dirinya sendiri.

Dalam Kebudayaan Cina modern, Konfusianisme telah ditolak oleh para intelektual pada awal abad ke-20 dengan jatuhnya Sistem Kekaisaran Cina. Hilangnya kepercayaan pada Kekaisaran diikuti juga oleh hilangnya kepercayaan atas ide moral Konfusianisme. Mulai dari Pemerintahan Cina Republik dan Republik Rakyat Cina, Konfusianisme telah kehilangan kredibilitasnya.

Akan tetapi saat ini, di mana Cina telah berusaha mencari jalan menuju ekonomi kapitalis dan pembangunan teknologi, masihkah ada tempat untuk Konfusianisme dalam kebudayaan Cina modern? Makalah ini bertujuan untuk menjawab dan menjelaskan masih relevankah nilai-nilai Konfusianisme dalam masa modern di mana pembangunan ekonomi berjalan pesat.

\section{KONFUSIANISME DI CINA}

Konfusianisme adalah ajaran dari Konfusius/Confucius atau dalam Bahasa Mandarin disebut Kongzi (孔子) yang merupakan filsuf besar dari Cina. Nama aslinya adalah Kong Qiu alias Zhong Ni.Ia lahir pada tahun 551 SM di Negara Lu. Ayahnya adalah seorang panglima perang. Ayahnya meninggal pada saat ia berumur tiga tahun sedangkan ibunya meninggal pada saat ia berumur 26 tahun. Konfusius wafat dalam usia 72 tahun pada tahun $479 \mathrm{SM}$

Ajaran pokok dari Konfusius adalah lima sifat mulia yang memiliki arti lima kebajikan, yaitu :

1). Ren (忍) yaitu cinta kasih yang universal yang tidak mementingkan diri sendiri tetapi mementingkan orang lain.

2). Yi 意 yaitu kebenaran atau pribadi luhur.

3). Li 礼 yaitu kesusilaan, sopan santun, rasa susila, dan budi pekerti.

4). Ci 慈 yaitu kebijaksanaan, pengertian, kearifan.

5). Xin 信, yaitu kejujuran kepercayaan, rasa untuk dapat dipercaya orang lain serta dapat memegang janji dan menepati janji.

Dalam Ajaran Agung ditekankan untuk dapat terciptanya keteraturan. Selaras dengan hal tersebut, Konfusius juga mengatur hubungan antar manusia dalam Prinsip Wulun (五论) yang berarti lima norma kesopanan dalam masyarakat yang mengatur hubungan antara:

1). raja dengan menteri, atau atasan dengan bawahan;

2). ayah dengan anak laki-laki;

3). suami dengan istri;

4). anak laki-laki dengan anak laki-laki; dan

5). hubungan antar teman. 
Keteraturan dalam suatu masyarakat adalah suatu pandangan yang harus diciptakan oleh Konfusius.Untuk dapat menciptakan keteraturan dalam masyarakat, manusia harus dapat mengatur keluarganya sendiri.Untuk dapat mengatur keluarga dan mengerjakan semua hal tersebut pertama-tama manusia harus dapat mengolah dirinya sendiri.Pengolahan diri membutuhkan koreksi diri, manusia harus tulus dan bersungguh-sungguh jika berhubungan dengan orang lain, selain itu manusia juga harus memperluas pengetahuan sampai tingkat yang paling tinggi.Pengolahan diri (self-cultivation) merupakan dasar dari segala sesuatu dan setiap manusia harus dapat melakukan pengolahan diri untuk mencapai hal yang menjadi tujuan dalam kehidupannya.( Wang Gungwu, 1995:9).

Konfusius dan murid-muridnya mengajarkan bagaimana seharusnya menjadi manusia yang bermoral, dan bagaimana penguasa harus sangat bermoral untuk dapat memerintah dan mengatur masyarakatnya, memiliki perasaan yang sensitive akan kebutuhan sosial dan ekonomi rakyatnya. Ada keterkaitan yang erat antara Konfusius dan pemerintahan Dinasti Han (汉朝, Han chao)(206 SM - 220), di mana para Konfusianis menjadi para pejabat kerajaan dan makin banyak keluarga-keluarga bangsawan yang berkuasa juga menjadi Konfusianis. Selama masa Dinasti Han sampai dengan Dinasti Tang (唐朝, Tang chao)(618-907), negara sangat mendukung Konfusianisme. Pada masa itulah Konfusianisme sangat menentukan bagaimana pemerintahan itu diatur. Hal ini dapat terlaksana karena adanya kontrol dari Konfusianisme dengan diberlakukannnya sistem ujian negara (科举, keju) bagi para pejabat negara.

Konfusianisme memegang peranan yang sangat penting dalam dalam pembentukan sejarah Cina, dan adalah tidak mungkin untuk memahami Cina pada saat sekarang ini tanpa mengacu pada sejarahnya. Nilai-nilai Konfusius sangat berakar dalam setiap ritual-ritual penting dalam keluarga dan kelompok kekerabatan. Struktur dasar keluarga mulai dari jia 家 (keluarga) sampai $z u$ 祖 (klen) merupakan dasar dari penerapanKonfusianisme. Seluruh kehidupan dan tingkah laku keluarga, adat istiadat, ritual, jaringan sosial masyarakat terpadu dalam pranata politik, ekonomi, dan sosial Konfusianisme yang tertata menurut Ajaran Agung.

Menurut Wang Gungwu, terdapat empat tingkatan yang dapat mempresentasikan para Konfusianis, yaitu:

1). Konfusianis Personal;

2). Konfusianis Patriarkat;

3). Konfusianis Birokrat, dan

4). Konfusianis Kerajaan.

Empat tingkatan Konfusianis yang disebutkan di atas, akan dijelaskan berikut di bawah ini. 


\section{KONFUSIANISME DI MASA MODERN}

Jika kita melihat Cina pada saat ini, hal-hal yang tertulis di atas menjadi sangat berbeda. Dalam Kebudayaan Cina modern, Konfusianisme telah ditolak oleh para intelektual pada awal abad ke-20 dengan jatuhnya Sistem Kekaisaran Cina. Hilangnya kepercayaan pada Kekaisaran diikuti juga oleh hilangnya kepercayaan atas ide moral Konfusianisme. Selain hilangnya kepercayaan atas ide moral Konfusianis, masyarakat juga kehilangan kepercayaan atas sastra Konfusianis yang dianggap gagal melayani tidak hanya kekaisaran tetapi juga peradaban Cinaitu sendiri. Konfusianisme telah ditolak baik pada masa Cina Republik dan juga pemerintahan RRC.

Cina saat ini sedang menuju ke jalan ekonomi kapitalis dan pembangunan teknologi untuk pembangunan Negara, apakah Konfusianisme saat ini masing penting dan berarti? Untuk menjawab pertanyaan ini, kita harus mengacu pada empat tingkatan Konfusianis yang telah disebutkan di atas, yaitu Konfusianis Personal, Konfusianis Patriarkat, Konfusianis Birokrat, dan Konfusianis Kerajaan atau pada saat ini kita mendefinisikannya sebagai Konfusianis Nasional ( Wang Gungwu, 1995:11).

Dalam bidang politik, sosial, dan ekonomi, Konfusianisme telah ditinggalkan dan hanya berpengaruh dalam lingkup pengajaran saja. Bagi kebanyakan orang awam dan intelektual, Konfusianisme menyimbolkan bayangan masa lalu, keterbelakangan, dan ketidakmampuan Cina. Pengolahan diri sebagai dasar ajaran ide Konfusianisme bermain pada tataran Konfusianis tingkat personal, sehingga Konfusianisme lebih nampak jelas pada tingkatan persona ( pribadi). Konfusianisme tidaklah penting seperti pada tingkat ideologi, atau pada tingkat nasional (Negara). Kebanyakan orang Cina adalah Konfusianis baik secara sadar maupun di bawah sadar tetapi tidak mengakuinya karena kebanyakan orang enggan berurusan dengan penguasa, akan tetapi orang Cina tidaklah menginginkan Konfusianisme sebagai suatu ideologi nasional atau Negara. Konfusianisme lebih bersifat pribadi atau personal yang diyakini sebagai suatu cara pengolahan diri.

Seperti diketahui sistem kekerabatan pada masyarakat Tiongkok adalah patrialisme dan kepala keluarga (jiazhang 家长) memegang peranan yang sangat penting dalam sistem sosial masyarakat Tiongkok, sehingga pada tingkatan Konfusianis selanjutnya yang akan kita bahas, adalah Konfusianis Patriarkat atau pada tingkat kepala keluarga. Pada tingkatan ini, Konfusianis tidaklah menjadi begitu penting lagi, karena saat ini masyarakat telah berubah, Banyak sekolah-sekolah dan pendidikan modern di Cina, khususnya di kota-kota besar, sistem keluarga tradisional dan struktur klen sangatlah sulit untuk dipertahankan. Perubahan dalam masyarakat seperti emansipasi wanita melalui kebebasan ekonomi, kesempatan kerja,semuanya menyebabkan sistem Konfusianisme pada tingkatan ini tidak dapat dipertahankan.

Dalam tingkat Birokrat, Konfusianisme masih memiliki peranan, ketika pemilihan dalam tingkat Birokrat untuk memilih para pejabat ditetapkan standar integritas personal 
yang tinggi dan kejujuran antar pejabat publik.Ide Konfusianisme tentang tingkah laku sosial, keselarasan, dan keteraturan sosial sangat berfungsi dalam pelayanan publik.

Pada tingkat negara, sudah dapat dipastikan tidak ada tempat bagi Konfusianis. Konfusianisme bukanlah suatu ideologi pada masa ini, sehingga Konfusianisme di Cina pada saat ini hanya tampak pada tataran personal atau pribadi dan pada tingkat birokrat.

Ide Konfusianisme tentang moral memiliki semanagat optimisme bahwa setiap orang dapat menjadi "orang suci", hal ini menunjukkan bahwa setiap orang memiliki potensi yang sama dan sederajat. Dengan demikian unsur positif Konfusianisme yang semacam ini tidak akan dapat dihilangkan atau ditekan oleh sitem kekuasaan apapun. Keadaan inilah yang akan terus berlangsung dalam situasi Cina yang berkembang dan modern.Konfusianisme tidak dapat dipisahkan dalam situasi Cina modern karena unsur-unsur Konfusianisme telah diwariskan dan diturunkan sampai saat ini baik secara implisit dalam doktrin Nasionalis, Komunis, prinsip, etos, pendapat public, dan sistem elit birokrasi. Ada hubungan antara antara “Tiga Prinsip Demokrasi (三民主义 sanmin zhuyi) Sun Yatsen (1866-1925); Nasionalisme, demokrasi, kesjahteraan rakyat dengan visi Konfusianisme mengenai 大同社会 datong shehui, masyarakat persatuan dunia. Begitu pula dengan komunisme yang mewarisi kode moral Konfusianisme, warisan tersembunyi ini yang menyebabkan bagi Konfusianisme untuk terus bertahan di dunia modern.

Pada awal tahun 1980-an Konfusianisme mulai bangkit kembali, bagaimana pun juga bangkitnya Konfusianisme bukan untuk mengembalikan tradisilama dan juga bukan untuk mengembalikan ajaran dan praktik lama tetapi karena nilai Konfusianisme yang telah turun temurun berakar dalam sistem masyarakat. Nilai moral dan spiritual Konfusianisme yang menitik beratkan pada tanggung jawab moral, pemahaman manusia tentang kehidupan yang diyakini dapat terus bertahan di masa yang akan datang.

\section{PENUTUP}

Konfusianisme sangat berperan penting dalam sejarah Cina dan membentuk sejarah Cina itu sendiri. Konfusianisme sebagai suatu ide filsafat yang menekankan pada keteraturan sosial dan etika selama ribuan tahun telah mengakar dan melebur menjadi satu dalam pranata masyarakat Cina.Nilai-nilai Konfusius sangat berakar dalam setiap ritual-ritual penting dalam keluarga dan kelompok kekerabatan. Struktur dasar keluarga mulai dari jia 家 (keluarga) sampai zu 祖 (klen) merupakan dasar dari suksesnya Konfusianisme. Seluruh kehidupan dan tingkah laku keluarga, adat istiadat, ritual, jaringan sosial masyarakat terpadu dalam pranata politik, ekonomi, dan sosial Konfusianisme yang tertata menurut Ajaran Agung.

Dalam tingkatan Kekaisaran, Konfusianisme memainkan peranan penting dalam mengatur pemerintahan karena semua para pejabat Negara adalah Konfusianis.Di mana untuk melegalkan hal tersebut diberlakukan sistem ujian Negara untuk memilih para pejabat mulai dari tingkat kabupaten, propinsi sampai Negara. 
Setelah jatuhnya sistem kekaisaran Cina pada 1911, berdirinya Republik Cina (1911) dan RRC (1949), Konfusianisme telah ditolak dan tidak mendapatkan kepercayaan masyarakat. Akan tetapi karena Konfusianis berada dalam empat tingkatan, yaitu personal, patriarkat, birokrat, dan nasional seperti telah disebutkan dalam pembahasan tersebut di atas, masih ada ruang bagi Konfusianisme yaitu pada tingkat personal atau pribadi. Pada tingkat tersebut, Konfusianisme masih terus ada dan bertahan karena dasar dari Ajaran Agung adalah pengolahan diri, sementara pengolahan diri bermain pada tataran tingkat personal.

Konfusianisme yang menekankan pada pengolahan diri dalam tingkat personal inilah yang dapat bertahan sekian lama dan dihormati serta menyebar ke seluruh tingkatan dan tetap ada dalam masyarakat Cina modern.

Konfusianisme memberikan sumbangan kepada masyarakat modern dalam hal perasaan moral, etika Konfusianisme yang menekankan pribadi atau diri sendiri sebagai pusat dari segala hubungan (wulun), tidak menekankan kepada hak pribadi individu, melainkan pada tanggung jawab individu dalam masyarakat. Tradisi Konfusianisme dapat memberikan kontribusi yang berarti bagi persatuan dan keharmonisan dunia (天 下一家 tianxia yi jia).

\section{DAFTAR PUSTAKA}

Legge, James. The Chinese Classics: Confucian Analects, the Great Learning and The Doctrine Mean. New York. 1894.

Wang, Gungwu. The Significance of Confucianism in Contemporary Chinese Culture, Asian Culture 19. 1995.

Wibowo, I. Belajar dari Tiongkok. Jakarta: Penerbit Buku Kompas. 2004.

Yao, Xinzhong. An Introduction to Confucianism. Cambridge: Cambridge University Press. 2000. 